\title{
Correction to: GIS based exploring of low-enthalpy geo-energy potentials in the Subsaharan area in Central Africa
}

\author{
Janvier Domra Kana (D) Noël Djongyang • Aretouyap Zakari $(\mathbb{D} \cdot$ \\ Njeudjang Kasi • Danwé Raïdandi • Philippe Njandjock Nouck • \\ William Teikeu Assastsé • Tabod Charles Tabod
}

Published online: 30 October 2021

(C) Springer Nature Switzerland AG 2021

\section{Correction to:}

Geomech. Geophys. Geo-energ. Geo-resour. (2021) 7:94

https://doi.org/10.1007/s40948-021-00290-1

In the publication of this article (Domra et al. 2021), there was an error in the reference of Fig. 1 and Fig. 5. error: 'Fig. 1 Technological variants of shallow geothermal use: a BHE and b GWSE; Fig. 5 Specific heat extraction rate (Erol 2011;MCS 2011;VDI-4640/ 12000)' should instead read: 'Fig. 1 Technological variants of shallow geothermal use: a BHE and b GWSE (Bayer et al. 2019); Fig. 5 Specific heat

The original article can be found online at https:// doi.org/10.1007/s40948-021-00290-1.

\section{J. D. Kana $(\bowtie)$}

Department of Mines, Petroleum and Water Ressource Exploration, The Faculty of Mines and Petroleum Industries, University of Maroua, PO Box 08, Kaele, Cameroon

e-mail: janvierkana@yahoo.fr

\section{J. D. Kana · N. Djongyang · N. Kasi}

Department of Renewable Energy, National Advanced Polytechnic School of Maroua, University of Maroua,

PO Box 46, Maroua, Cameroon

A. Zakari

Department of Architecture and Engineering Art/Institute of Fine Arts, University of Dschang,

PO Box 31, Foumban, Cameroon extraction rate (Bayer et al. 2019; Erol 2011;MCS 2011;VDI-4640/12000)'.

\section{Reference}

Bayer P, Attard G, Blum P, Menberg K (2019) The geothermal potential of cities. Renew Sustain Energy Rev 106:17-30

Publisher's Note Springer Nature remains neutral with regard to jurisdictional claims in published maps and institutional affiliations.

\section{Raïdandi}

Department of Mechanical Engineering, National Advanced Polytechnic School, University of Yaoundé I, PO Box 8390, Yaoundé, Cameroon

P. N. Nouck - W. T. Assastsé - T. C. Tabod Department of Physics, Faculty of Science, University of Yaoundé I, PO Box 812, Yaoundé, Cameroon

T. C. Tabod

Department of Physics, Faculty of Science, University of Bamenda, PO Box 39, Bamenda, Cameroon 